\title{
SIMULATING THE ECONOMIC VIABILITY OF CRAWFISH PRODUCTION: A TWO-STAGE APPROACH
}

\author{
Amy C. Hasegawa \\ University of Delaware \\ Department of Food and Resource \\ Economics \\ Townsend Hall \\ Newark, DE 19717, U.S.A.
}

\author{
Conrado M. Gempesaw
}

University of Delaware

Office of the Vice Provost for

Academic Programs and Planning

234 Hullihen Hall

Newark, DE 19716, U.S.A.
William H. Daniels

Bernard R. Petrosky

Delaware State University

Department of Agriculture and

Natural Resources

1200 North Dupont Highway

Dover, DE 19901, U.S.A.

\begin{abstract}
The purpose of this study is to determine if raising eastern white river crawfish (Procambarus acutus acutus) in the Mid-Atlantic region year-round is economically feasible. The possibility for economic success, or even survival, will be examined with the use of a two-stage dynamicstochastic simulation modeling framework. Six simulation models were created in ProModel 4.0 to mimic crawfish farms with different components. Information collected from the ProModel experiments were then used in @ Risk, a Microsoft Excel add-in, in order to determine the economic viability of crawfish farms using capital budgeting methods. Preliminary results suggest that crawfish farming in the Mid-Atlantic region can be feasible, assuming the consumer demand exists.
\end{abstract}

\section{INTRODUCTION}

Simulation can be used as a method of empirically ascertaining the chances of an event occurring by means of experimentation. The evaluation of new enterprises can be a costly venture when accomplished by trial and error. A much less expensive approach would be to simulate a new enterprise without actually incurring the risk and costs of a true business. Appraising the financial feasibility of a new crawfish farm is no exception. The use of simulation software such as ProModel 4.0 and @Risk can simplify this analysis by applying stochastic processes and generating relevant data necessary for the economic evaluation of the proposed enterprise.

Several studies have used simulation to evaluate the viability of agricultural production. Gempesaw and Bacon (1993) used a dynamic-stochastic simulation model in evaluating the risks and returns associated with the specialization and diversification in the production of hybrid striped bass, catfish, and poultry in the Mid-Atlantic region. Albay et al. (1995) described a forward and backward linkage agricultural production simulation model, which is applied to evaluate the profitability of poultry, beef, grain, and kenaf farms. A comprehensive discussion on the history of applying farm-level simulation models is given by Klein and Narayanan (1992). Previous agricultural simulation models focus more on the economic and financial aspects rather than the technical efficiency involved in the production process. In this study, equal importance is placed on the economic and technical efficiency of crawfish production using a two-stage approach.

\section{CASE STUDY}

Aquaculture is defined as the regulation and cultivation of water plants and animals for human use or consumption. Crawfish production is an example of an aquaculture enterprise. The majority of crawfish produced is used for food and originates in Louisiana. Other regions are now attempting forays into this market. Currently, the most popular species of crawfish marketed commercially in the United States is Procambarus clarkii, more commonly known as the red swamp crawfish, because they are most abundant in Louisiana. White river crawfish, Procambarus acutus acutus, inhabits the eastern United States. Red swamp and white river crawfish are similar in appearance, but the white river crawfish have been shown to have a faster growth rate and can become much larger than the red swamp variety (Holdich and Lowery 1988). Since 1994, biological and production research has been conducted at Delaware State University to determine the optimal conditions for crawfish production in the Mid-Atlantic region.

In order to assess the economic viability of crawfish production, it was necessary to collect financial information regarding output prices, costs of production and investment requirements. These are outlined in table 1. The majority of the financial data is taken from the cost 
and returns budget data prepared by Boucher and Gillespe (1998). This information was compiled from a survey of commercial crawfish producers in Louisiana. This particular approach was necessary because the industry in the Mid-Atlantic region is relatively very small and financial information is not available. A ten-year planning horizon is used in the study to determine whether the proposed enterprise could survive over this long-run scenario.

\section{METHODOLOGY}

In view of the basic objectives in this study, two simulation packages were used. ProModel 4.0 was used for the process efficiency portion and @Risk was used to evaluate the economic viability of the project.

ProModel 4.0 has the ability to take stochastic variables and to capture their interdependencies and, perhaps, inefficiencies in a production system (Promodel Corp. 1997). The software allows the user to enter proposed system reorganization and determine its viability without the expense of implementing a potentially inefficient design. ProModel can aid in the identification of possible bottlenecks and other inefficient portions of the production process. Other advantages include the availability of animation, coherent output reporting, and a comprehensible programming structure. One drawback of ProModel is that its random number generator follows a pseudo-random number process. Changing the seed number each time a series of replications is run can rectify this problem. There has been limited use of this particular package in the field of aquaculture thus far. A related aim of this study is to evaluate the proficiency of this software in this distinct application.

Six distinct models were created in ProModel 4.0 to achieve the goals outlined in the introduction. Different farm configurations aid in finding the most efficient outcomes. All six have a hatchery and a market and ponds of different sizes. Originally, each individual crawfish was defined as one entity in ProModel. This program took almost four days to run because of the enormous volume. Therefore, each entity in ProModel was defined as one thousand crawfish. The new models were easier to run, and far more rapid than the initial ones.

For each model, an alternate scenario was created with an increased mortality rate. These are referred to with a lowercase "a" after the model number. These models were created to present the "worst-case" scenario.

The first model incorporates four ponds of one acre each, a hatchery, a nursery, and a market. Initial stocking should be in a ratio of 1:1 between female and male crawfish. The brood stock begins in the hatchery in October or November. The initial brood stock was caught and estimated to contain one thousand male adult crawfish and an equal number of female adult crawfish. Brood stock in subsequent years is taken from the amount produced in the previous year. Each female is predicted to produce, at least one hundred eggs, averaging two hundred eggs per female. Some can produce as much as five hundred. This range in egg volume is represented by a triangular probability distribution of juvenile arrivals. After the juveniles are independent, the brood stock is discarded. Then, the juveniles are transported to the nursery where they will remain until they are mature enough to be placed in ponds, around the middle of March. Stocking in the ponds is limited to a maximum of approximately twenty-seven hundred pounds of crawfish per acre (Holdich and Lowery 1988). From the hatchery to the nursery, the juveniles were programmed to have a survival rate of sixty percent. The survival rates of mature crawfish transported from the nursery to the ponds and from the ponds to the market were calculated to be ninetyfive percent. The configuration of the various models are listed in tabular form in Table 1 below.

Table 1: Model Configurations in ProModel

\begin{tabular}{|c|c|c|c|c|}
\hline Model & $\begin{array}{c}\text { Hatchery } \\
\text { Survival }\end{array}$ & Nursery & Ponds & $\begin{array}{c}\text { Pond } \\
\text { Survival }\end{array}$ \\
\hline Model 1 & $60 \%$ & $\mathrm{Y}$ & $4-1$ acre & $95 \%$ \\
\hline Model 1a & $60 \%$ & $\mathrm{Y}$ & $4-1$ acre & $55 \%$ \\
\hline Model 2 & $45 \%$ & $\mathrm{~N}$ & $4-1$ acre & $95 \%$ \\
\hline Model 2a & $45 \%$ & $\mathrm{~N}$ & $4-1$ acre & $55 \%$ \\
\hline Model 3 & $60 \%$ & $\mathrm{Y}$ & $2-10$ acre & $95 \%$ \\
\hline Model 3a & $60 \%$ & $\mathrm{Y}$ & $2-10$ acre & $55 \%$ \\
\hline Model 4 & $45 \%$ & $\mathrm{~N}$ & $2-10$ acre & $95 \%$ \\
\hline Model 4a & $45 \%$ & $\mathrm{~N}$ & $2-10$ acre & $55 \%$ \\
\hline Model 5 & $60 \%$ & $\mathrm{Y}$ & $4-10$ acre & $95 \%$ \\
\hline Model 5a & $60 \%$ & $\mathrm{Y}$ & $4-10$ acre & $55 \%$ \\
\hline Model 6 & $45 \%$ & $\mathrm{~N}$ & $4-10$ acre & $95 \%$ \\
\hline Model 6a & $45 \%$ & $\mathrm{~N}$ & $4-10$ acre & $55 \%$ \\
\hline
\end{tabular}

The second model incorporates four ponds of one acre each, a hatchery, and a market. The processing in this model is similar to the aforementioned model except for the increased volume in stocking. Brood stock numbers, in this case, were increased to twelve hundred each of mature male and female crawfish, double the numbers for the first model. Because of the omission of the nursery step, the survival rates decrease from sixty percent for juveniles transported from the hatchery to the ponds to forty-five percent, and ninety-five percent for adult transport from the ponds to market. However, the per-acre cost of creating four one-acre ponds is higher than four ten-acre ponds. Also, the majority of equipment needed on the farm, such as boats and tractors, can handle a larger volume of area, which may cause such a small farm to be inefficient. Thus, the next pond sizes to be modeled are increased to ten acres for the efficient use of the fixed assets of the proposed venture. 
The third model is similar to the first, except for the inclusion of two ten-acre ponds in place of the four oneacre ponds. The rates of survival outlined in the description of the first model remain the same for this one. To reiterate, the model contains a hatchery, nursery, two ponds of ten acres each, and a market. Since this is a much larger farm than the previous two, encompassing twentyone acres, the brood stock can be increased to include five thousand male and five thousand female adult crawfish. The timeline specified in the description of the first model applies in this one as well.

The fourth model is essentially the same as the third model with the nursery step removed. Survival rates explicated in model two also are pertinent in model four. Brood stock of six thousand males and six thousand females create juvenile crawfish that enter the production process of moving form the hatchery directly to the ponds.

The last two models duplicate the third and fourth models aside from the number of ponds used and the volume of land necessary. Both are made up of forty-one acres of land, forty of which are occupied by four ten-acre ponds. The fifth and sixth model are identical to each other except for the omission of the nursery step in the sixth model.

Each of the models was run ten times to simulate a full ten-year period in order to capture the farm's performance in the long run. The various farms were simulated for oneyear intervals because in a ten-year interval, breakdowns for each year are not available. Each year is represented by one hundred iterations.

The second objective was met through the use of capital budgeting techniques based on a simulation framework. Capital budgeting techniques are used to evaluate economic decisions involving long term horizons with large amounts of monetary investment required. This was achieved using @Risk, an add-in for Microsoft Excel which is a financial evaluation software package that obtains results in the form of a probability distribution function. This software enables the user to represent uncertain values in data with various probability distribution functions. For instance, it has the flexibility of permitting Latin Hypercube sampling which can more accurately represent the distribution of values in the input probability distribution. The technique used in Latin Hypercube sampling is more simply put as sampling without replacement (Palisade Corp. 1998). The investment data requirements are presented in Table 2 . @ Risk also calculates the breakeven price, net present value (NPV), and the internal rate of return (IRR) of the investment. These capital budgeting measures are important in assessing the economic feasibility of the proposed enterprise. For the purpose of this study, only the breakeven price results will be reported. The other capital budgeting results are available from the authors upon request.

Table 2: Initial Investment Assumptions

\begin{tabular}{|c|c|}
\hline Investment & Cost \\
\hline Land & $\$ 1,800.00 /$ acre \\
\hline Pond Construction (ten-acre ponds) & $\$ 5,519.84 /$ acre \\
\hline Pond Construction (one-acre ponds) & $\$ 9,614.80 /$ acre \\
\hline Hatchery Building & $\$ 10,000.00$ \\
\hline Nursery Building (when applicable) & $\$ 10,000.00$ \\
\hline Fertilizer Buggies & $\$ 5,500.00$ \\
\hline Tractors & $\$ 11,300.00$ \\
\hline Boat, Motor, and Trailer & $\$ 3,150.00$ \\
\hline Combine & $\$ 6,500.00$ \\
\hline Mower and Plow & $\$ 6,500.00$ \\
\hline
\end{tabular}

\section{DISCUSSION OF RESULTS}

Each of the six distinct models had four financial scenarios associated with it. The first assumed the producer owns none of the capital required for the proposed crawfish farm. Second, the scenario where the producer owns the land for the farm is considered. The next scenario assumed that the producer owns all of the equipment and the land, but must invest in the ponds, hatchery building, and the nursery building, when applicable. Finally, it is assumed that the producer already owns everything except for the hatchery and nursery (when required).

A detailed summary of the results is listed in Table 3. It is clear that the most profitable scenario is the situation where the producer had four ten-acre ponds, and must only invest in the hatchery and nursery buildings. The simulation results from @ Risk show that the highest breakeven price was estimated at $\$ 5.77$ per pound for the four one-acre pond, no nursery model with the increased mortality (model 2a). On the other hand, the lowest breakeven price was estimated at $\$ 0.61$ per pound for the four ten-acre pond model. The simulation results also show the financial impacts of higher mortality rates. For instance, in model 5, the breakeven price was estimated at $\$ 0.61$ per pound at favorable mortality rates. However, at higher mortality rates, the breakeven price increases to $\$ 1.07$ per pound. In Louisiana, the average harvest can sell for one to two dollars a pound, with the producer making around sixty to eighty cents per pound. At these prices, a MidAtlantic crawfish venture could be profitable, depending on the farm layout. It would seem that the proposed venture of a crawfish farm is economically feasible, and would most likely be profitable if the appropriate farm size, assets and production level can be achieved and maintained. 
Table 3 : @ Risk Results from Models 1-6

\begin{tabular}{|c|c|c|c|}
\hline Model & Description & Investment & $\begin{array}{c}\text { Breakeven } \\
\text { Price } \\
\end{array}$ \\
\hline Model 1 & $\begin{array}{l}\text { From } \\
\text { scratch }\end{array}$ & $\$ 100,409.21$ & $\$ 2.91$ \\
\hline (four-one & Own Land & $\$ 91,409.21$ & $\$ 2.56$ \\
\hline \multirow[t]{2}{*}{$\begin{array}{c}\text { acre } \\
\text { ponds }\end{array}$} & $\begin{array}{c}\text { Own land \& } \\
\text { equipment }\end{array}$ & $\$ 58,459.21$ & $\$ 1.90$ \\
\hline & $\begin{array}{c}\text { Own all but } \\
\text { hatchery \& } \\
\text { nursery }\end{array}$ & $\$ 20,000.00$ & $\$ 1.12$ \\
\hline \multirow[t]{4}{*}{ Model 1a } & $\begin{array}{l}\text { From } \\
\text { scratch }\end{array}$ & $\$ 100,409.21$ & $\$ 4.70$ \\
\hline & Own Land & $\$ 91,409.21$ & $\$ 4.40$ \\
\hline & $\begin{array}{c}\text { Own land \& } \\
\text { equipment }\end{array}$ & $\$ 58,459.21$ & $\$ 3.19$ \\
\hline & $\begin{array}{c}\text { Own all but } \\
\text { hatchery \& } \\
\text { nursery }\end{array}$ & $\$ 20,000.00$ & $\$ 1.90$ \\
\hline Model 2 & $\begin{array}{c}\text { From } \\
\text { scratch }\end{array}$ & $\$ 90,409.21$ & $\$ 2.99$ \\
\hline (four-one & Own Land & $\$ 81,409.21$ & $\$ 2.81$ \\
\hline $\begin{array}{c}\text { acre } \\
\text { ponds }\end{array}$ & $\begin{array}{c}\text { Own land \& } \\
\text { equipment }\end{array}$ & $\$ 48,459.21$ & $\$ 2.00$ \\
\hline $\begin{array}{c}\text { no } \\
\text { nursery) }\end{array}$ & $\begin{array}{l}\text { Own all but } \\
\text { hatchery }\end{array}$ & $\$ 10,000.00$ & $\$ 1.20$ \\
\hline \multirow[t]{4}{*}{ Model 2a } & $\begin{array}{c}\text { From } \\
\text { scratch }\end{array}$ & $\$ 90,409.21$ & $\$ 5.77$ \\
\hline & Own Land & $\$ 81,409.21$ & $\$ 5.50$ \\
\hline & $\begin{array}{c}\text { Own land \& } \\
\text { equipment }\end{array}$ & $\$ 48,459.21$ & $\$ 4.00$ \\
\hline & $\begin{array}{l}\text { Own all but } \\
\text { hatchery }\end{array}$ & $\$ 10,000.00$ & $\$ 2.11$ \\
\hline Model 3 & $\begin{array}{l}\text { From } \\
\text { scratch }\end{array}$ & $\$ 201,146.70$ & $\$ 1.40$ \\
\hline (two-ten & Own Land & $\$ 163,346.70$ & $\$ 1.21$ \\
\hline $\begin{array}{c}\text { acre } \\
\text { ponds) }\end{array}$ & $\begin{array}{c}\text { Own land \& } \\
\text { equipment }\end{array}$ & $\$ 130,396.70$ & $\$ 1.08$ \\
\hline \multirow{5}{*}{ Model 3a } & $\begin{array}{l}\text { Own all but } \\
\text { hatchery }\end{array}$ & $\$ 20,000.00$ & $\$ 0.66$ \\
\hline & $\begin{array}{l}\text { From } \\
\text { scratch }\end{array}$ & $\$ 201,146.70$ & $\$ 2.34$ \\
\hline & Own Land & $\$ 163,346.70$ & $\$ 2.03$ \\
\hline & $\begin{array}{c}\text { Own land \& } \\
\text { equipment }\end{array}$ & $\$ 130,396.70$ & $\$ 1.84$ \\
\hline & $\begin{array}{c}\text { Own all but } \\
\text { hatchery }\end{array}$ & $\$ 20,000.00$ & $\$ 1.14$ \\
\hline Model 4 & $\begin{array}{c}\text { From } \\
\text { scratch }\end{array}$ & $\$ 191,146.70$ & $\$ 1.53$ \\
\hline (two-ten & Own Land & $\$ 153,346.70$ & $\$ 1.33$ \\
\hline $\begin{array}{l}\text { acre } \\
\text { ponds }\end{array}$ & $\begin{array}{c}\text { Own land \& } \\
\text { equipment }\end{array}$ & $\$ 120,396.70$ & $\$ 1.21$ \\
\hline $\begin{array}{c}\text { no } \\
\text { nursery) }\end{array}$ & $\begin{array}{c}\text { Own all but } \\
\text { hatchery }\end{array}$ & $\$ 10,000.00$ & $\$ 0.73$ \\
\hline
\end{tabular}

\begin{tabular}{|c|c|c|c|}
\hline Model & Description & Investment & $\begin{array}{c}\text { Breakeven } \\
\text { Price } \\
\end{array}$ \\
\hline \multirow[t]{4}{*}{ Model 4a } & $\begin{array}{l}\text { From } \\
\text { scratch }\end{array}$ & $\$ 191,146.70$ & $\$ 2.55$ \\
\hline & Own Land & $\$ 153,346.70$ & $\$ 2.28$ \\
\hline & $\begin{array}{c}\text { Own land \& } \\
\text { equipment }\end{array}$ & $\$ 120,396.70$ & $\$ 2.04$ \\
\hline & $\begin{array}{c}\text { Own all but } \\
\text { hatchery }\end{array}$ & $\$ 10,000.00$ & $\$ 1.22$ \\
\hline Model 5 & $\begin{array}{l}\text { From } \\
\text { scratch }\end{array}$ & $\$ 347,543.30$ & $\$ 1.26$ \\
\hline (four-ten & Own Land & $\$ 273,743.30$ & $\$ 1.07$ \\
\hline \multirow[t]{2}{*}{$\begin{array}{c}\text { acre } \\
\text { ponds }\end{array}$} & $\begin{array}{c}\text { Own land \& } \\
\text { equipment }\end{array}$ & $\$ 240,793.30$ & $\$ 1.01$ \\
\hline & $\begin{array}{c}\text { Own all but } \\
\text { hatchery \& } \\
\text { nursery }\end{array}$ & $\$ 20,000.00$ & $\$ 0.61$ \\
\hline \multirow[t]{4}{*}{ Model 5a } & $\begin{array}{l}\text { From } \\
\text { scratch }\end{array}$ & $\$ 347,543.30$ & $\$ 2.18$ \\
\hline & Own Land & $\$ 273,743.30$ & $\$ 1.95$ \\
\hline & $\begin{array}{c}\text { Own land \& } \\
\text { equipment }\end{array}$ & $\$ 240,793.30$ & $\$ 1.77$ \\
\hline & $\begin{array}{c}\text { Own all but } \\
\text { hatchery \& } \\
\text { nursery }\end{array}$ & $\$ 20,000.00$ & $\$ 1.07$ \\
\hline Model 6 & $\begin{array}{l}\text { From } \\
\text { scratch }\end{array}$ & $\$ 337,543.30$ & $\$ 1.36$ \\
\hline (four-ten & Own Land & $\$ 263,743.30$ & $\$ 1.22$ \\
\hline $\begin{array}{c}\text { acre } \\
\text { ponds }\end{array}$ & $\begin{array}{c}\text { Own land \& } \\
\text { equipment }\end{array}$ & $\$ 230,793.30$ & $\$ 1.16$ \\
\hline $\begin{array}{c}\text { no } \\
\text { nursery) }\end{array}$ & $\begin{array}{l}\text { Own all but } \\
\text { hatchery }\end{array}$ & $\$ 10,000.00$ & $\$ 0.67$ \\
\hline \multirow[t]{4}{*}{ Model 6a } & $\begin{array}{l}\text { From } \\
\text { scratch }\end{array}$ & $\$ 337,543.30$ & $\$ 2.37$ \\
\hline & Own Land & $\$ 263,743.30$ & $\$ 2.12$ \\
\hline & $\begin{array}{c}\text { Own land \& } \\
\text { equipment }\end{array}$ & $\$ 230,793.30$ & $\$ 1.95$ \\
\hline & $\begin{array}{c}\text { Own all but } \\
\text { hatchery }\end{array}$ & $\$ 10,000.00$ & $\$ 1.17$ \\
\hline
\end{tabular}

Because there are currently no large, established crawfish farms in the Mid-Atlantic region, the asking prices should be possible to attain. Louisiana has many crawfish farms and a one to two dollar selling price seems reasonable, but a producer in this area should be able to get a little more. Crawfish sold in the Mid-Atlantic region mainly come from either Louisiana or are imported from China. Therefore, the crawfish are quite costly for the consumer. If crawfish were to be produced in the MidAtlantic region, then consumers of this area would not bear the expense of transport and will receive a much fresher product. 


\section{CONCLUSIONS AND IMPLICATIONS}

The results from ProModel seem to look promising for a new crawfish business enterprise. Even with half or less than half of the initial crop surviving, the harvest is reasonably large. Because of such abundant production, this business venture has the possibility of surviving. It should be noted that the models used in this study do not take into account growth or expansion of the farm. Nevertheless, even without any expansion, the simulation results, particularly for the large size ponds provide reasonable breakeven prices.

A study conducted in 1995 examined the market for crawfish and other forms of seafood in Delmarva (Robinson, 1995). This study investigated results from surveys sent to wholesalers, retailers, and consumers using a logit model with maximum likelihood estimation.

The majority of both the retailers and the wholesalers participating in the aforementioned study admitted that they did not sell crawfish. Their reasoning was that there was no demand for crawfish. The consumers, on the other hand, are aware of the product, but forty-three percent replied that they did not eat crawfish because there was a lack of availability. It would seem that there is a communications gap between those who sell crawfish and the consumers. Stores won't sell it because there is a lack of demand, but consumers won't buy it because there is a lack of supply.

Only twenty-three percent of those surveyed answered that they did eat crawfish. The majority of the consumers who do not currently eat crawfish said that it was because they never had before. About a third of those who answered mentioned that they did not buy crawfish because they do not know how to prepare it. Perhaps this gap in communication could be remedied by a good advertisement campaign and more visibility. If this gap in information could be bridged, there is a potential market for crawfish in the Mid-Atlantic region.

The goals of this study have been met, for the most part. The first objective was to determine the financial feasibility of a crawfish farm in the Mid-Atlantic region. This was attained by studying production numbers from the simulation models in ProModel, then incorporating these results into @Risk for financial analysis. The minimum selling price for crawfish for entrepreneurial survival was determined in each financial scenario. These were discovered to be in reasonable ranges. Therefore, assuming that current prices do not decrease dramatically, the proposed business could probably survive financially.

The second objective attempted to analyze the advantages of combining the two simulation software packages into one study. This was shown to be a good combination in evaluating business enterprises. These two packages have advantages over a single simulation package.
This study has evaluated that a crawfish enterprise in the Mid-Atlantic region has the potential to be a viable enterprise. With reasonable breakeven market price levels, the proposed farms show great economic promise. The farms have the potential to be more profitable with a differentiated crop, but that could be a topic for further study. In addition, it is also critical that a market demand study be conducted to assess at what prices consumers would be willing to purchase crawfish.

The fundamental contribution of a simulation model is that the analyst is able to gather pertinent observations about the proposed system over time. These observations or simulated data are then used to calculate the various measures of business performance which, in this study, focused on capital budgeting techniques. This study has employed the simulation approach to represent crawfish production as a system. The results indicate that economies of size are an important factor in the feasibility of crawfish production in the Mid-Atlantic region. However, the interested reader should be cautioned that this study only focused on the "supply" side and assumed that whatever is produced can be sold. As noted previously, it is equally important that a study of the "demand" side be undertaken as well.

\section{ACKNOWLEDGEMENTS}

This research project was partially funded by USDA/CREES/HEP \#96-38814-2872.

\section{REFERENCES}

Albay, F., Gempesaw, C., Bacon, J., \& Munasinghe, L. A forward and Backward Linkage Agricultural Production Simulation Model, Proceedings of the 1995 Winter Simulation Conference, pp. 963-968, December 1995.

Boucher, Robert W. \& Gillespe, Jeffrey M.; Projected Costs and Returns for Crawfish and Catfish Production in Louisiana 1998; Louisiana State University Agricultural Center; 1998.

Gempesaw, C. \& Bacon, J. Broilers and Aquaculture: A Case of Agricultural Output Diversification Journal of the American Society of Farm Managers and Rural Appraisers, 57(1), pp. 18-26, May 1993.

Gempesaw, C., Wirth, F., Bacon, J., \& Vaughn, G. The Economics of Intergration Versus Specialization: The Case of Hybrid Striped Bass Pond Culture. University of Delaware College of Agricultural Sciences, Newark, Delaware, June 1991.

Holdich, David M. \& Lowery, Roger S. Freshwater Crawfish: Biology, Management, and Exploitation, Timber Press, Portland, OR, 1988.

Klein, K. \& Narayanan, S. Farm Level Models: A Review of Developments, Concepts and Applications in 
Canada, Canadian Journal of Agricultural Economics 40(3) pp. 351-368, November 1992.

The ProModel Corporation, The ProModel Manual, Orem, Utah, 1997.

Palisade Corporation, Risk Analysis for Spreadsheets, Newfield, NY, 1998

Robinson, Christopher L. Analysis of Consumer, Wholesaler, and Retailer Perceptions About Selected Marketing Issues Regarding Fish and Seafood Products, Unpublished Master's Thesis, University of Delaware, Newark, DE, 1995.

\section{AUTHOR BIOGRAPHIES}

AMY C. HASEGAWA is a graduate student at the University of Delaware in Newark pursuing a master's degree in Operations Research. She holds a B.A. in economics and mathematics from Lawrence University in Appleton, Wisconsin. She is a member of INFORMS.

CONRADO M. GEMPESAW is a Professor at the Department of Food and Resource Economics, University of Delaware. He completed his M.S. degree from West Virginia University and his Ph.D. degree from the Pennsylvania State University. His research interests are in agribusiness finance, production economics and international trade.

WILLIAM H. DANIELS is a research associate professor and extension specialist in aquaculture at Delaware State University in Dover. He holds a Ph.D. in Wildlife and Fisheries Sciences from Mississippi State University as well as a M.S. in Wildlife and Fisheries Sciences from Texas A\&M University and a B.S. in Biology from the University of South Alabama. His research interests include nutrition and physiology of fish and crustaceans and general production methods of aquaculture species. $\mathrm{He}$ is a member of the World Aquaculture Society, the International Association of Astacologists, and the Crustacean Society. 